$\begin{array}{ll}\text { Volume } & : 04 \\ \text { Nomor } & : 01 \\ \text { Bulan } & : \text { Januari } \\ \text { Tahun } & : 2018 \\ \text { http } & : / / \text { ejurnal.pps.ung.ac.id/index.php/AKSARA/index }\end{array}$

\title{
Optimalisasi Sarana Prasarana Water Park Tiara Kota Gorontalo
}

\author{
Bambang Suharto, Lisna Bantulu \\ Universitas Negeri Gorontalo \\ bambangsuharto@ung.ac.id
}

\begin{abstract}
The purpose of this study is to investigate the optimization of water infrastructure and facilities in the city of Gorontalo Tiara boom as well as to determine the condition of water infrastructure boom Tiara Gorontalo. Data analysis techniques used in this study is a qualitative description techniques by processing the data in getting on the field of observation, interviews and documentation. The results of this study, discusses the infrastructure and constraints that exist in water boom Tiara Gorontalo, in particular the benefits of each of the infrastructure that is provided in the water boom Tiara Gorontalo. Because based on my survey results are still a lot of infrastructure that has not been feasible in use that can endanger visitors or tourists, and while that which is feasible in use but have not functioned. Therefore infrastructure water boom Tiara Gorontalo need to be on guard and be noticed again that the safety of visitors or tourists are guaranteed and infrastructures which provide better so that visitors and tourists can feel satisfied and happy after visiting the water boom Tiara Gorontalo.
\end{abstract}

Keywords: Optimization, Infrastructure, Water boom Tiara Gorontalo

\section{PENDAHULUAN}

Mengawali tahun 2016 sebagai dampak adanya perkembangan pariwisata di Gorontalo, pertumbuhan kunjungan wisatawan mancanegara yang langsung datang ke Gorontalo secara kontinue mengalami kenaikan. Namun demikian, dengan berbagai upaya, akhirnya memperlihatkan hasil yang menjanjikan dengan peningkatan jumlah kunjungan wisatawan mancanegara diakhir tahun 2012 sebesar 59\%. Usaha untuk meningkatkan jumlah kunjungan wisatawan domestik, merupakan salah satu wacana penting pemerintah seperti yang telah dicanangkan yaitu target jumlah kunjungan wisatawan sebanyak 6 juta orang melalui program pemerintah yaitu "Visit Indonesia Year". Upaya-upaya peningkatan kunjungan wisatawan akan sia-sia jika tidak diimbangi oleh perbaikan sarana dan prasarana pariwisata. Ada beberapa macam sarana kepariwisataan yang saling melengkapi (terpadu) di samping sebagai upaya untuk meningkatkan jumlah kedatangan wisatawan juga untuk memperpanjang lama tinggal wisatawan. Sarana kepariwisataan tersebut antara lain: yang merupakan sarana pokok berupa hotel, motel, bar, restaurant, travel agent, tour operator, tourist transportation,

Water Boom Tiara dalam meningkatkan pelayanan kepada tourism baik domestik maupun asing melakukan pengoptimalan terhadap sarana prasarana yang tersedia. Di antara sarana prasarana yang ada adalah tempat hiburan, tempat bermain, tempat-tempat duduk, dan sarana prasarana lainnya. Pengoptimalan sarana prasarana tersebut dimaksudkan untuk meningkaatkan pelayanan kepada 


$\begin{array}{ll}\text { Volume } & : 04 \\ \text { Nomor } & : 01 \\ \text { Bulan } & : \text { Januari } \\ \text { Tahun } & : 2018 \\ \text { http } & : / / \text { jurnal.pps.ung.ac.id/index.php/AKSARA/index }\end{array}$

masyarakat sehingga dapat bersaing dengan tempat wisata lainnya. Sebagaimana yang dinyatakan oleh Tjiptono (1996:24) dewasa ini semakin diyakini bahwa kunci utama untuk memenangkan persaingan adalah memberikan nilai dan kepuasan kepada pengunjung melalui penyampaian produk dan pelayanan berkualitas dengan harga bersaing, yang pada akhirnya loyalitas pengunjung harus didapat untuk menjadi "repeater guest".

Sarana prasarana yang terdapat di Water Boom Tiara merupakan fasilitas yang disediakan untuk meningkatkan kunjungan wisatawan. Sarana prasarana tersebut masih terbatas pada peningkatan pelayanan terhadap wisatawan dosmetik karena belum dilengkapi dengan tempat penginapan dan tempat kuliner yang memadai. Ketidaktersediaan fasilitas penginapan dan rumah makan dikarenakan area waterboom tidak terlalu luas untuk pembangunan kedua sarana tersebut. Namun waterboom Tiara dekat dengan beberapa penginapan dan hotel di Kota Gorontalo.

\section{KAJIAN PUSTAKA \\ Hakikat Optimalisasi}

Dalam beberapa literatur manajemen, tidak dijelaskan secara tegas pengertian optimalisasi, namun dalam (Depdikbud, 1995:628) adalah optimalisasi berasal dari kata optimal yang berarti terbaik, tertinggi jadi optimalisasi adalah suatu proses meninggikan atau meningkatkan. Optimalisasi berasal dari kata optimal yang artinya, paling baik, paling tinggi, atau paling menguntungkan. (Hoetomo,2005:356). Pengertian Optimalisasi menurut Wikipedia adalah serangkaian proses yang dilakukan secara sistematis yang bertujuan untuk meniggikan volume dan kualitas trafik kunjungan melalui mesin mencari menuju situs web tertentu dengan memanfaatkan mekanisme kerja atau alogaritma mesin pencari tersebut. Berdasarkan pengertian di atas penulis menyimpulkan pengertian optimalisasi adalah suatu proses yang dilakukan dengan cara terbaik dalam suatu pekerjaan untuk mendapatkan keuntungan tanpa adanya harus mengurangi kualitas pekerjaan.

Optimalisai banyak juga diartikan sebagai ukuran dimana semua kebutuhan dapat dipenuhi dari kegiatan-kegiatan yang dilaksanakan. Menurut Winardi (1999: 363) Optimalisasi adalah ukuran yang menyebabkan tercapainya tujuan sedangkan jika dipandang dari sudut usaha, Optimalisasi adalah usaha memaksimalkan kegiatan sehingga mewujudkan keuntungan yang diinginkan atau dikehendaki. Dari uraian tersebut diketahui bahwa optimalisasi hanya dapat diwujudkan apabila dalam pewujudannya secara efektif dan efisien. Dalam penyelenggaraan organisasi, senantiasa tujuan diarahkan untuk mencapai hasil secara efektif dan efisien agar optimal.

\section{Hakikat Pariwisata}

Pariwisata adalah istilah yang diberikan apabila seseorang wisatawan melakukan perjalanan itu sendiri, atau dengan kata lain aktivitas dan kejadian yang terjadi ketika seseorang pengunjung melakukan perjalanan (Sutrisno, 1998, hal: 23). Pariwisata secara singkat dapat dirumuskan sebagai kegiatan dalam masyarakat yang berhubungan dengan wisatawan (Soekadijo, 2000: 2). 


$\begin{array}{ll}\text { Volume } & : 04 \\ \text { Nomor } & : 01 \\ \text { Bulan } & : \text { Januari } \\ \text { Tahun } & : 2018 \\ \text { http } & : / / \text { jurnal.pps.ung.ac.id/index.php/AKSARA/index }\end{array}$

Pariwisata merupakan bagian yang tidak terpisahkan dari kehidupan manusia terutama menyangkut kegiatan sosial dan ekonomi. Diawali dari kegiatan yang semula hanya dinikmati oleh segelintir orang-orang yang relatif kaya pada awal abad ke-20, kini telah menjadi bagian dari hak azasi manusia. Hal ini terjadi tidak hanya di Negara maju tetapi mulai dirasakan pula di negara berkembang. Indonesia sebagai Negara yang sedang berkembang dalam tahap pembangunannya, berusaha membangun industri pariwisata sebagai salah satu cara untuk mencapai neraca perdagangan luar negeri yang berimbang. Melalui industri ini diharapkan pemasukan devisa dapat bertambah (Pendit, 2002: 54).

Perencanaan pariwisata haruslah di dasarkan pada kondisi dan daya dukung dengan maksud menciptakan interaksi jangka panjang yang saling menguntungkan di antara pencapaian tujuan pembangunan pariwisata, peningkatan kesejahteraan masyarakat setempat, dan berkelanjutan daya dukung lingkungan di masa mendatang (Fandeli,1995: 12).

\section{Waterboom}

Waterboom adalah sebuah taman hiburan yang memili area/wahana permainan air seperti water slides, splash pads, spraygrounds (water playgrounds), lazy rivers, dan rekreasi lainnya seperti berenang dan mandi air. 15 Menurut kamus bahasa inggris waterpark adalah: Water: air, boom: taman public atau area yang digunakan untuk masyarakat. Menurut kamus bahasa Indonesia taman adalah suatu tempat yang menyenangkan untuk hiburan atau rekreasi sedangkan air merupakan cairan yang tidak memiliki bentuk sendiri. Maka waterpark adalah suatu taman hiburan atau rekreasi yang menggunakan elemen air sebagai media wahananya (Sharpe, William E. and Swistock, Bryan., 2008: 54).

\section{Air}

Komponen Dalam Water Park, meliputi :

Air adalah benda cair seperti yang biasa terdapat di sumur, sungai, danau, yg mendidih pada suhu $100^{\circ} \mathrm{C}$ dan membeku pada suhu $0^{\circ} \mathrm{C}$.

Air pada waterboom dilakukan konservasi. Konservasi adalah pelestarian atau perlindungan. Secara harfiah, konservasi berasal dari bahasa Inggris, (Inggris) Conservation yang artinya pelestarian atau perlindungan. Sedangkan menurut ilmu lingkungan, Konservasi adalah 20 : (1) Upaya efisiensi dari penggunaan energi, produksi, transmisi, atau distribusi yang berakibat pada pengurangan konsumsi energi di lain pihak menyediakan jasa yang sama tingkatannya. (2) Upaya perlindungan dan pengelolaan yang hati-hati terhadap lingkungan dan sumber daya alam, (3) (fisik) Pengelolaan terhadap kuantitas tertentu yang stabil sepanjang reaksi kiamia atau transformasi fisik.

Beberapa system pengelolaan air bekas antara lain:

a. Sumur Resapan

Salah satu upaya untuk meningkatkan kemampuan tanah meresapkan air hujan yaitu melalui pembuatan sumur resapan.

b. Biopori

Lubang resapan biopori adalah metode resapan air dengan cara meningkatkan daya resap air pada tanah. Biopori itu sendiri adalah pori-pori 


$\begin{array}{ll}\text { Volume } & : 04 \\ \text { Nomor } & : 01 \\ \text { Bulan } & : \text { Januari } \\ \text { Tahun } & : 2018 \\ \text { http } & : / / \text { jurnal.pps.ung.ac.id/index.php/AKSARA/index }\end{array}$

berbentuk lubang (terowongan kecil) yang dibuat oleh aktivitas fauna tanah atau akar tanaman.

\section{c. Memanen Air Hujan (Rain Water Harvesting)}

Air hujan yang dipanen dapat digunakan untuk multi tujuan seperti menyiram tanaman, mencuci, mandi dan bahkan dapat digunakan untuk memasak jika kualitas air tersebut memenuhi standar kesehatan (Sharpe, William E., \& Swistock, Bryan, 2008; Worm, Janette \& van Hattum, Tim, 2006).

d. Daur Ulang

Pengolahan limbah, atau pengolahan air limbah domestik, adalah proses penghilangan kontaminan dari air limbah dan limbah rumah tangga, baik limpasan (efluen) maupun domestik. Hal ini meliputi proses fisika, kimia, dan biologi untuk menghilangkan kontaminan fisik, kimia dan biologis. Tujuannya adalah untuk menghasilkan aliran limbah (atau efluen yang telah diolah) dan limbah padat atau lumpur yang cocok untuk pembuangan atau penggunaan kembali terhadap lingkungan. 21

\section{Kolam}

Menurut Peraturan MenKes RI dan Keputusan Direktur Jend PPM danPLP tentang persyaratan kesehatan kolam renang dan pemandian umum tahun 1992, kolam renang adalah suatu usaha bagi umum yang menyediakan tempat untuk berenang, berekreasi, berolahraga serta jasa pelayanan lainnya,menggunakan air bersih yang telah diolah.

Persyaratan kolam renang sesuai dengan Peraturan MenKes RI dan Keputusan Direktur Jend PPM dan PLP tentang persyaratan kesehatan kolam renang dan pemandian umum tahun 1992 menyangkut beberapa hal:

a. Umum

Lingkungan kolam renang dan pemandian umum harus selalu dalam keadaan bersih dan dapat mencegah kemungkinan kejadian penularan penyakit serta tidak memungkinkan bersarang dan berkembang biaknya vector penular penyakit. Bangunan kolam renang dan pemandian umum serta peralatan yang dipergunakan harus memenuhi persyaratan kesehatan dan dapat mencegah terjadinya kecelakaan.

b Tata Bangunan

Setiap bangunan di lingkungan kolam renang dan pemandian umum harusditata dan dipergunakan sesuai dengan fungsinya, serta memenuhi persyaratan kesehatan antara lain tidak mengakibatkan pencemaran terhadap air kolam renang dan pemandian umum

\section{Wahana Permainan}

\section{a. Kolam Air yang Mengalir (Streaming Pool)}

Streaming Pool merupakan kolam air yang mengalir, dan biasanya mengikuti jalur yang telah direncanakan ban pelampung untuk menikmati streaming pool ini.

b. Kolam Ombak (Wave Pool)

Wave pool adalah kolam renang dengan gelombang yang diciptakan sedemikian rupa sehingga menyerupai laut. Wave Pool merupakan salah satu komponen utama yang harus ada pada sebuah Water Park. Wave Pool biasanya 


$\begin{array}{ll}\text { Volume } & : 04 \\ \text { Nomor } & : 01 \\ \text { Bulan } & : \text { Januari } \\ \text { Tahun } & : 2018 \\ \text { http } & : \text { //ejurnal.pps.ung.ac.id/index.php/AKSARA/index }\end{array}$

lebih besar daripada kolam air yang lainnya, untuk itu wave pool biasanya diletakkan di dekat taman atau area terbuka

c. Seluncur Air (Water Slide)

Ada 2 jenis water slide, yakni Non-Inflated water slide dan Inflated water slide (dengan pompa udara).

\section{Taman}

Water Park haruslah memiliki area hijau, yakni dengan menyediakan taman terbuka, yang fungsinya untuk peneduh, penghijauan dan sebagai resapan. Taman yang akan disediakan bisa disesuaikan dengan tema yang diinginkan, misalnya Taman tropis, taman bunga dan sebagainya. Dalam kamus bahasa Indonesia taman adalah kebun yang ditanami dengan bunga-bunga dan sebagainya (tempat bersenang-senang)

\section{METODE PENELITIAN}

Pelaksanaan penelitian ini akan dilakukan selama 3 bulan terhitung sejak bulan Mei sampai dengan Juli 2016. Penelitian ini bertempat di Waterboom Tiara Kota Gorontalo. Penelitian ini menggunakan metode kualitatif dengan rancangan studi kasus. Sugiyono (2007) mengemukakan bahwa penelitian kualitatif disebut juga penelitian naturalistik, karena penelitiannya dilakukan pada kondisi yang alamiah (natural setting). Karena peneliti berusaha mencari informasi suatu fenomena tentang optimalisasi sarana prasarana di Waterboom Tiara Kota Gorontalo.

Alasan penggunaan metode kualitatif dengan rancangan studi kasus adalah karena penelitian ini bertujuan untuk mendeskripsikan optimalisasi sarana prasarana di Waterboom Tiara Kota Gorontalo. Selain itu, sesuai dengan hakikat penelitian kualitatif, yaitu: (1) optimalisasi sarana prasarana di Waterboom Tiara Kota Gorontalo harus dilakukan secara seimbang dan integratif sehingga dengan menggunakan penelitian kualitatif akan dapat dipahami secara utuh, terfokus sesuai konteks di mana peristiwa terjadi; (2) hubungan antara peneliti dengan subyek yang diteliti lebih peka sehingga dengan mudah dapat dilakukan secara mendalam terhadap obyek yang diteliti; (3) penelitian kualitatif bersifat ilmiah, deskripsi dan induktif serta berupaya menemukan makna dari suatu fenomena yang terjadi Lincoln dan Guba (dalam Moleong, 2000)

Analisis data merupakan upaya mencari dan menata data secara sistematis catatan hasil observasi, wawancara dan sejenisnya. Analisis dilakukan secara terus menerus dari awal sampai akhir penelitian berdasarkan keadaan data di lapangan untuk meningkatkan pemahaman peneliti tentang kasus yang diteliti dan menyajikan sebagai temuan bagi orang lain. Bogdan dan Biklen (dalam Sugiyono, 2007) menyatakan bahwa analisis data adalah proses mencari dan menyusun secara sistematis data yang diperoleh dari hasil wawancara, catatan lapangan, dan bahanbahan lain, sehingga dapat mudah difahami, dan temuannya dapat diinformasikan kepada orang lain.

Menurut Miles dan Huberman (dalam Sugiyono, 2007) mangatakan bahwa proses analisis data deskriptif melalui tiga alur kegiatan yang berlangsung secara simultan, yaitu: (1) Collection Data, (2) reduksi data atau penyederhanaan data, (3) paparan data, (4) penarikan kesimpulan. 


$\begin{array}{ll}\text { Volume } & : 04 \\ \text { Nomor } & : 01 \\ \text { Bulan } & : \text { Januari } \\ \text { Tahun } & : 2018 \\ \text { http } & : / / \text { ejurnal.pps.ung.ac.id/index.php/AKSARA/index }\end{array}$

\section{HASIL PENELITIAN DAN PEMBAHASAN}

\section{Kondisi Sarana dan Prasarana Waterboom Tiara Park}

Waterboom Tiara Park adalah sebuah wahana rekreasi air atau theme park di Kota Gorontalo, lokasi ini sangat cocok anda kunjungi saat liburan bersama keluarga. Sejak dibuka pada tanggal 25 Desember 2012, Tiara Park menjadi salah satu tempat favorit untuk dikunjungi. Tiara Park adalah tempat rekreasi di alam terbuka dengan luas wahana lebih kurang 3 ha. Wahananya terdiri dari kolam renang, garden park, bola balon, berperahu, kebun binatang kecil, kora-kora, sepeda air, dan wahana air lainnya. Waterboom tiara park terletak di Kelurahan Dulomo Utara Kecamatan Kota Utara Kota Gorontalo. Harga tiket masuk ke lokasi ini adalah Rp.20.000/orang, malam hari pun wahana ini terbuka dengan tiket lebih murah, Rp.10.000/orang untuk masuk. Lokasi ini benar-benar direkomendasikan untuk Anda santai bersama keluarga, teman atau bahkan pasangan special Waterboom Tiara Park didirikan sejak tahun 2012 oleh Tiara. Waterboom Tiara Park terletak di Kelurahan Dulomo Utara Kecamatan Kota Utara Kota Gorontalo Provinsi Gorontalo.

Berdasarkan hasil pengamatan terhadap Waterboom Tiara Park terdapat beberapa sarana dan prasarana yang tersedia yaitu:

a. Kolam Renang

Terdapat 1 buah kolam renang anak-anak dan 1 buah kolam renang dewasa.

Berdasarkan hasil wawancara dengan karyawan waterboom (Ibu Herda) pada tanggal 24 Juli 2016 bahwa:

Kolam renang dewasa dan anak-anak biasanya paling ramai dikunjungi oleh wisatawan domestic pada hari minggu atau hari-hari libur lainnya.Pengunjung ada yang belajar berenang namun juga ada yang latihan. Untuk keamanan penggunaan kolam renang tersedia ahli renang di waterboom ini untuk menolong pengunjung yang mengalami kesulitan atau kecelakaan dalam berenang dan membimbing anak-anak yang ingin belajar berenang

b. Danau Buatan

Terdapat fasilitas sepeda air yang bejumlah 4 buah di danau buatan.

Berdasarkan hasil wawancara dengan pengunjung waterboom tiara (Ibu Nadia) tanggal 24 Juli 2016 bahwa;

Danau buatan ini dipergunakan untuk santai dengan keluarga dengan memanfaatkan wahana bermain seperti perahu bebek dan lain-lain.

c. Restoran

Terdapat beberapa buah restoran yang ada di waterboom tiara termaksud rumah makan Dapur Gorontalo. Di rumah makan Dapur Gorontalo tersedia makanan khas Gorontalo seperti: Ikan woku, Kua Asam, Milu Siram, dan lain sebagainnya.

Berdasarkan hasil wawancara dengan pemilik waterboom tiara (Ibu Tiara) pada tanggal 10 Juni 2016 bahwa:

Restoran menyediakan berbagai jenis masakan khas Gorontalo. Hal ini disengaja oleh pimpinan untuk memperkenalkan kuliner Gorontalo kepada 


$\begin{array}{ll}\text { Volume } & : 04 \\ \text { Nomor } & : 01 \\ \text { Bulan } & : \text { Januari } \\ \text { Tahun } & : 2018 \\ \text { http } & : / / \text { jurnal.pps.ung.ac.id/index.php/AKSARA/index }\end{array}$

pengunjung waterboom ini. Meskipun terdapat beberapa pengunjung yang menghendaki masakan lainnya tetap dilayani dengan baik.

d. Panggung

Terdapat 3 buah panggung 1 panggung digunakan untuk menyelenggarakan acara dan 2 difungsikan untuk kegiatan-kegiatan lainnya.

Panggung disediakan oleh pemilik waterboom tiara kepada pengunjung yang ingin melaksanakan acara-acara atau pertemuan-pertemuan tertentu. Biasanya acara yang diselenggarakan oleh keluarga berupa ulang tahun, sedangkan oleh perusahaan-perusahaan dipergunakan untuk acara kesenian. Demikian pula oleh instansi-instansi pemerintah yang melaksanakan kegiatan ditempat ini.

e. Motor dan Mobil RTV

Terdapat 2 buah motor RTV dan 2 buah mobil RTV. Motor-motor tersebut merupakan kenderaan operasional waterboom tiara dalam melayani pengunjung yang mengalami kesulitan dalam transportasi.

f. Shelter

Terdapat 21 Shelter di Waterboom Tiara Park. Shelter-shelter tersebut dipergunakan oleh pengunjung untuk beristirahat atau bercengkrama dengan keluarga atau handai taulan.

g. Kebun Binatang Mini

Terdapat sebuah kebun binatang yang didalamnya ada beberapa jenis burung, buaya, angsa, dan monyet.

Menurut hasil wawancara peneliti dengan informan karyawan waterboom tiara pada tanggal 12 Juni 2016 bahwa:

Keberadaan binatang-binatang ditempat ini sebenarnya bukan merupakan suguhan utama waterboom tiara, tetapi hanya sebagai pelengkap fasilitas waterboom. Hal ini untuk memberikan nuansa tersendiri bagi pengunjung agar tidak bosan dengan tempat ini. Selain bisa menikmati suasana waterboom, pengunjung juga dapat menikmati tontonan yang menarik yaitu binatang-binatang bahwa mereka bisa bercengkrama dengan binatang tersebut.

h. Bianglala Mini

i. Kora-Kora

j. Karaoke

Di waterboom tiara tersedia juga tempat karaoke yang dapat dimanfaatkan oleh pengunjung untuk bernyanyi. Bila ingin karaoke pengunjung dapat mengeluarkan biaya yang cukup murah yaitu Rp 50.000 untuk satu jam. Namun bila pengunjung ingin menggunakan ruang karaoke dalam jangka waktu yang lama biasanya pengelola waterboom memberikan diskon yang cukup menarik pengunjung.

k. Meeting Room

Meeting room yang tersedia pada waterboom tiara dipergunakan oleh pengunjung untuk mengadakan rapat atau pertemuan-pertemuan penting lainnya. Biaya meeting room bervariasi tergantung kesepakatan antara pengunjung dengan pengelola waterboom. Biasanya harga untuk satu kali pertemuan sebesar Rp 30.000 per kepala. 


$\begin{array}{ll}\text { Volume } & : 04 \\ \text { Nomor } & : 01 \\ \text { Bulan } & : \text { Januari } \\ \text { Tahun } & : 2018 \\ \text { http } & : / / \text { jurnal.pps.ung.ac.id/index.php/AKSARA/index }\end{array}$

1. Taman

Taman merupakan sarana yang disediakan oleh pengelola waterboom tiara untuk memperindah waterboom. Adanya taman memberikan nuansa indah dan pemandangan yang menarik sehingga akan menambah daya tarik wisatawan untuk berkunjung ketempat tersebut.

m. Kamar Bilas dan Toilet

Kamar bilas dan toilet di waterboom park berjumlah 8 unit. Kamar bilas dan toilet tersebut dipergunakan oleh pengunjung untuk membersihkan badan setelah berenang atau untuk mengganti pakaian. Selain itu fasilitas ini mempermudah pengunjung untuk membuang hajat baik hajat kecil maupun besar.

n. Mushola

Pengelola waterboom tiara menyadari bahwa pengujung waterpark membutuhkan sarana beribadah selain menikmati keindahan tempat ini maupun untuk bermain. Oleh sebab itu pengelola menyediakan mushola meskipun dalam ukuran yang kecil.

\section{Optimalisasi Sarana dan Prasarana}

Sarana prasarana yang tersedia di waterboom cukup memadai namun perlu adanya optimalisasi pada keseluruhan sarana prasarana tersebut untuk meningkatkan jumlah pengunjung. Hasil pengamatan terhadap optimalisasi sarana prasarana waterboom tiara dapat diuraikan sebagai berikut:

a. Sarana yang Perlu Diperbaiki

Terdapat beberapa sarana yang perlu diperbaiki yaitu bianglala mini, korakora karena kondisi wahana yang benar-benar rusak dan tidak dapat difungsikan.

Menurut hasil wawancara peneliti dengan karyawan waterboom tiara bahwa:

Terdapat beberapa sarana yang rusak dikarenakan digunakan oleh pengunjung dan mungkin pula karena pengaruh usia sarana tersebut. Selain itu mungkin karena kurangnya pemeliharaan yang dilakukan sehingga sarana prasarana tersebut rusak.

b. Sarana yang Perlu Pengadaan

Adapun beberapa yang perlu diadakan yaitu seperti Water Slide (Seluncur Air), Kolam Air yang Mengalir (Streaming Pool), Kolam Ombak (Wave Pool), toko souvenir atau cindera mata, pos penyelamatan, locker dan penitipan barang, penyewaan pakaian renang, fasilitas kesehatan.

Menurut hasil wawancara peneliti dengan informan pengujung pada tanggal 13 Juni 2016 bahwa:

Beberapa fasilitas yang masih kurang ditempat ini adalah souvenir atau kenang-kenangan yang bisa dibeli setelah berkunjung ketempat ini. Setidaknya ada sesuatu yang menjadi ciri khas tempat ini dan menjadi salah satu daya tarik pengunjung. Fasilitas lainnya yang kurang dan belum tersedia adalah penitipan barang, penyewaan pakaian renang, dan juga fasilitas kesehatan. Fasilitas tersebut sangat kami butuhkan untuk kenyamanan dan keselamatan dalam berrekreasi ditempat ini.

c. Sarana yang Perlu Difungsikan 


$\begin{array}{ll}\text { Volume } & : 04 \\ \text { Nomor } & : 01 \\ \text { Bulan } & : \text { Januari } \\ \text { Tahun } & : 2018 \\ \text { http } & : / / \text { jurnal.pps.ung.ac.id/index.php/AKSARA/index }\end{array}$

Terdapat beberapa sarana yang kondisinya memadai tetapi belum difungsikan seperti kolam renang anak-anak dan kolam renang dewasa, Meeting Room, Karaoke, Aula, Mobil dan Motor RTV, tetapi akan difungsikan lagi pada bulan Juli. Terdapat juga kebun binatang mini tetapi sudah tidak difungsikan lagi. Wateboom Tiara Park lebih memfungsikan restoran yang bernama "Dapur Gorontalo" daripada sarana-sarana lainnya.

Menurut hasil wawancara peneliti dengan informan pengujung pada tanggal 13 Juni 2016 bahwa:

Kolam renang belum berfungsi secara optimal, karena masih dalam taraf perbaikan. Kolam renang sebaiknya difungsikan secara optimal, karena dengan sarana prasarana tersebut maka pengunjung akan semakin tertarik dengan keberadaan waterboom ini. Hal ini dikarenakan sebagian besar masyarakat suka berenang baik untuk belajar maupun untuk latihan. Walaupun nantinya dikenakan biaya tersendiri namun tetap segera difungsikan..

d. Sarana yang Perlu Ditata

Taman dan Shelter-Shelter yang terdapat di Waterboom Tiara Park kurang tertata dengan baik. Kebersihannya masih kurang terjaga, dan Shelter yang kurang tertata dengan rapi.

\section{KESIMPULAN DAN SARAN}

Kondisi Sarana dan Prasarana Waterboom Tiara Park umumnya baik dan cukup memadai. Sarana prasarana tersebut meliputi: Kolam Renang, Danau Buatan, Restoran, Panggung, Motor dan Mobil RTV, Shelter, Kebun Binatang Mini, Bianglala Mini, Kora-Kora, Karaoke, Meeting Room, Aula, Taman, Kamar Bilas dan Toilet, dan Mushola. Kendala Optimalisasi Sarana Prasarana adalah pembiayaan, tenaga ahli dalam pemeliharaan serta kurangnya kesadaran pengunjung untuk merawat, memelihara dan menjaga keamanan sarana prasarana yang terdapat di waterboom tiara.

\section{DAFTAR PUSTAKA}

Anonim, 2009. U.U. RI NO. 10 Tahun 2009 Tentang Kepariwisataan.

Depdikbud. 1995. Kamus Besar Bahasa Indonesia. Jakarta : Balai Pustaka

Fandeli, Chafid. 1995. Dasar-Dasar Manajemen Kepariwisataan Alam. Yogyakarta : Penerbit Liberty

Hoetomo. 2005. Kamus Lengkap Bahasa Indonesia. Jakarta: Mitra Pelajar.

K. Yin, Robert. 2002. Studi Kasus (Desain dan Metode). Jakarta. PT. Raja GrafindoPersada.

Karyono, Hari. 1997. Kepariwisataan. Jakarta: Grasindo

Moleong Lexy J. 2000, Metodologi Penelitian Kualitatif, Bandung: Remaja Rosda karya

Pendit, 2002. Perencanaan Kepariwisataan Alam. Yogyakarta: fakultas Kehutanan Universitas Gajahmada

Pitana, I Gede. 2002. ìKebijakan dan Strategi Pemerintah Daerah Bali dalam Pembangunan Pariwisata. Pada Seminar Nasional Pariwisata Bali the Last 
or the Lost Paradisê̂. Pembangunan Pariwisata yang Berkelanjutan. Denpasar: Universitas Udayana.

Puja Astawa I.B.G. 2002. Pola Pengembangan Pariwisata Terpadu Bertumpu Pada Model Pemberdayaan Masyarakat di Wilayah Bali Tengah. Denpasar: UNUD

Sharpe, William E. and Swistock, Bryan., 2008, Household Water Conservation, College of Agricultural Sciences, Agricultural Research and Cooperative Extension College of Agricultural Sciences, The Pennsylvania State University.

Soekadijo,R.G., 2000, Anatomi Pariwisata, Jakarta Gremedia Pustaka Utama

Sugiyono. 2007. Metode Penelitian Kuantitatif Kualitatif dan R\&D. Bandung: Alfabeta

Sutrisno, 1998. Psikologi Pariwisata. Jakarta: Yayasan Obor Indonesia. Hanke

Tirtadinata MR, Fachruddin L, 1996. Daya Tarik dan Pengelolaan Agrowisata. Depok: Penebar Swadaya.

Winardi, 1999, Pengantar Manajemen Penjualan, Bandung: PT. Citra Aditya. Bakti

Worm, Janette \& Hattum, Tim van., 2006, Rainwater Harvesting For Domestic Use, Agrodok 43,Agromisa Foundation and CTA, Wageningen.

Yoeti, Oka. 1997. Perencanaan dan Pengembangan Pariwisata. PT Pradnya. Paramita. Jakarta 